\title{
EVALUATION OF ACTIVITY OF SOME THYMOL-BASED FORMULATIONS FOR CONTROLLING HONEY BEE VARROOSIS.
}

Abdel Samed, A. M. '; Nadia M. Abd El-Moein'; M. E. Ramadan², H. A. El-Doksh ${ }^{3}$; M. S. Abdel-Lateef ${ }^{1}$ and R. F. Mohamed ${ }^{3}$

${ }^{1}$ Biochemistry Department, Faculty of Agriculture, Cairo University.

2 Biochemistry Department, Faculty of Agriculture, Minya University.

${ }^{3}$ Central Agricultural Pesticides Laboratory, Dokki, Giza.

\begin{abstract}
Two under-experimentation thymol-based formulations (tablets, Var-stop and strips, Var-away) were tested on twelve beehives in a commercial private apiary located in El-Minia governorate. The apiary trial was carried out during September October 2005. The main goals were to determine their effectiveness against Varroa distructor, taking into account natural mite mortality in control hives and to determine the residues of thymol in honey and wax. Both formulations significantly reduced the levels of mite infestation of adult bees, their varrocidal effectiveness according to the recommendations of the European Group for Integrated Varroa control were 97\%and 93\% for Var-stop and Var-away, respectively. Residues found in honey collected from the nest were $2.1 \mathrm{mg} / \mathrm{kg}$ for Var-stop and $1.7 \mathrm{mg} / \mathrm{kg}$ for Var-away. The residues were higher in wax (371 mg/kg for Var-stop and $475 \mathrm{mg} / \mathrm{kg}$ for Var-away).
\end{abstract}

\section{INTRODUCTION}

Varroosis of the honey bee (Apis mellifera L.) is a disease caused by the most destructive ectoparasitic mite Varroa distructor (Anderson and Trueman, 2000), which was first described on the Asian honey bee, Apis cerana. The new host infestation (Apis mellifera) occurred in the 1950,s when European productive bees were introduced to Asia. Since this time, varroosis has been spreading in all continents, thus requiring effective disease control methods and chemical treatments because of the great danger of the disease for beekeeping (Colin, 1990). The first $V$. distructor mite detection in Egypt was in September 1987 at El-Arish region. By September 1989, this mite had become widespread, and by the autumn 1990 a heavy infestation was found in many parts of Egypt, and many apiaries were nearly destroyed (Abou-Zeid and Ghoniemy, 1993). Different products; chemical and natural; are currently used for controlling this mite infestation. However, this mite still cause severe damage in apiaries because of its higher reproduction rate than its host (DE Ruijter, 1987), and the adaptation between the mite and the host's life cycle (Haenel and Koeniger 1986). Additionally, V. destructor is developing resistance to the most common chemical acaricides fluvalinate and coumaphose (Elzen et al.,1998. Milani 1999, Elzen et al., 2000). Other synthetic Varroa treatment such as flumethrine and bromopropylate leave toxic residues (Lodesani et al.,1992). Thus, there is an urgent need for an alternative treatments such as organic acids and essential oil constituents that are effective, and do not leave toxic residues in honey and wax. Essential oil constituents such as thymol (5-methyl-2-isopropyl phenol) has demonstrated a varroacidal activity not only in laboratory assays, but also in 
Abdel Samed, A. M. et al.

field in Europe (Imdorf et al.,1999) and in north America (Calderone,1999).Different thymol-based formulations have been studied to improve acaricide effectiveness, attempting to control the phenol release by different carriers. Thymol formulations significantly reduced the levels of the mite infestation of adult bees and sealed brood (Floris et al., 2004). The environmental conditions, colony condition, and the carrier of the active ingredient play an important role in the Thymol effectiveness against Varroa (Baggio et al., 2004). Some of these formulations such as Apilife VAR, Thymovar, and Apiguard are registered as a control of Varroa in different countries.

The present work aimed to determine the efficacy of the two underexperimentation thymol-based formulations Var-stop and Var-away, and the thymol residues in honey and wax under Egyptian conditions.

\section{MATERIALS AND METHODS}

Apiary The present investigation was conducted in a commercial private apiary located in El-Minya governorate. Before the trial, natural mite mortality was monitored for three days to obtain three homogeneous experimental groups. The trial was carried out during September - October 2005 on twelve colonies, divided to three groups of four hives (two treated and one control). The colonies were nearly the same strength, and were headed by first hybrid Carniolen queens.

Hives The colonies were housed in Langstroth hives, with a removable sticky bottom insert, protected with a net of 8 mesh.

Administration Mode.

The colonies were treated as follows:

Var-stop $90 \%$ thymol tablets, each contains $10 \mathrm{~g}$ of thymol .Three tablets (once a week for three weeks) were divided into two parts and placed on the top of the hive frames.

Var-away $\mathbf{4 2 . 5 \%}$ thymol strips, each contains $5 \mathrm{~g}$ of thymol .Six strips (twice a week for three weeks) were placed on the top of the hive frames. If present, the residues of previous doses of the two formulations were removed when further administrations were applied. After treatment, further oxalic acid $(3 \%)$ treatment (control treatment) was carried out to kill surviving mites and residual number of mites was collected for 14 days after oxalic acid treatment.

The dead mites were counted twice a week. Total acaricidal effectiveness calculated according to the formula published by European Group for Integrated Varroa control. (Anonymous, 1999).

$$
\text { Efficacy }(\%)=\frac{\text { No.Tr. } \times 100}{\text { No.Tr. }+ \text { No.ControlTr } .}
$$

Where (No. Tr.) is the number of mites killed by the treatment and (No. Control Tr.) is the number of mites killed by the control treatment. 
The efficacy of $n$th application is given by the following formula,

$$
A_{n}(\%)=\frac{N_{n} \times 100}{T_{N}-T_{n-1}}
$$

Where $N_{n}$ is the number of mites collected during the days following the $n$th application $\left(A_{n}\right), T N$ the total number of collected mites ( 3 application +oxalic acid control) and $T_{n}-1$ the number of collected mites before the $n$th application (Colin,1990).

To determine thymol residues, honey and wax samples were collected before and after treatment. Honey samples were collected from unsealed cells of two comps in the brood nest. Wax samples were collected by cutting $3 \mathrm{~cm}^{2}$ from two wax frames.

Chemicals: The two formulations; Var-stop and Var-away; were obtained from the Central Agricultural Pesticides Laboratory (Dokki- GizaEgypt).Thymol $99 \%$ was purchased from Loba Chemie (India).The HPLC grade solvents; acetone, methanol, and diethyl ether; were purchased from Merck (UK).

\section{Thymol Extraction :-}

Thymol Extraction Procedure from honey and wax according to Floris et al. (2004).

\section{Extraction Procedure from honey:}

One gram of honey was weighed in a $15 \mathrm{ml}$ screw- capped tube and dissolved in $2 \mathrm{ml}$ of water. Two milliliters of diethyl ether were added, and the tube was agitated $(10 \mathrm{~min})$ in a rotary shaker. The phases were allowed to separate, and an aliquot of the extract was injected into a GC.

\section{Extraction Procedure from wax.}

$0.5 \mathrm{~g}$ of wax was weighed in a $25 \mathrm{ml}$ screw- capped tube, $5 \mathrm{ml}$ of methanol/ water (1:1) were added, and the tube was plunged in hot water at $70{ }^{\circ} \mathrm{C}$ until the wax dissolved, and then agitated for $1 \mathrm{~min}$ in vortex. After cooling at room temperature, $5 \mathrm{ml}$ of diethyl ether were added, and the tube was agitated for $15 \mathrm{~min}$ in a rotary shaker. The phases were allowed to separate, the ether extract was centrifuged and an aliquot was injected into a GC.

Recovery Assay. Untreated samples of honey and wax were fortified with $0.1 \mathrm{mg} / \mathrm{kg}$ thymol and processed according to the procedure described above.

\section{Apparatus and Chromatography.}

Thymol residues in honey and wax samples were analyzed using a HPGLC 5890 gas chromatograph equipped with a flame ionization detector (FID) and split- split less injector. Separation was carried out on a HP-1, a methyl silicon gum column $30 \mathrm{~m} \times 0.53 \mathrm{~mm}, 0.88 \mu \mathrm{m}$ film thickness. The air and hydrogen flows for the FID flame were at 100 and $75 \mathrm{ml} / \mathrm{min}$, respectively. The carrier gas (nitrogen) flow rate was $4 \mathrm{ml} / \mathrm{min}$. The oven 
temperature was programmed as follows: $60^{\circ} \mathrm{C}$ hold $5 \mathrm{~min}$, raised to $130^{\circ} \mathrm{C}$ $\left(2^{\circ} \mathrm{C} / \mathrm{min}\right)$ hold $4 \mathrm{~min}$, raised to $180^{\circ} \mathrm{C}\left(10^{\circ} \mathrm{C} / \mathrm{min}\right)$.

\section{Statistical analysis.}

The data were analyzed by analysis of variance (ANOVA). When the Ftests were significant, means were separated applying least significant difference (LSD) and Duncan's test (SPSS 7.5.1 1996).

\section{RESULTS AND DISCUSSION}

\section{Efficacy}

Results in Table (1) show a significant difference in the treatment efficacy against Varroa mite between the three experimental groups, Varstop , Var-away , and untreated group ( $P<0.001, \alpha=0.05$, One way ANOVA). However, there is no significant difference between the two formulations, Var-stop and Var-away $(P=0.401, \alpha=0.05)$. The efficacy was $97.8 \% \pm 0.8$ for Var-stop and $95.75 \% \pm 1.5$ for Var-away. The mean numbers of collected mites/colony during treatment were $433.5 \pm 267.9$, $322.2 \pm 75.2$, and $96.5 \pm 43.6$, for Var-stop , Var-away, and untreated group, respectively.

There is no significant difference in efficacy between the two formulations in the first application $(P=0.479, S E=5.410, \alpha=0.05)$, and the third application $(P=0.242$, SE $=6.969, \alpha=0.05)$. However, there is a significant difference between them in the second application $(P=0.014$, SE $=4.009, \alpha=0.05$ ).

The obtained results are in agreement with those of Baggio et al. (2004) for the thymol-based acaricide Apilife VAR. The treatment was more effective than that described by Mattila and Otis (1999), and Gregorc (2005) for the thymol-based acaricide, Apiguard. It is also higher than the efficacy obtained by Lindberge et al. (2000) for the essential oil constituent, thymol, in a laboratorial study. However, it was lower than the efficacy of Apilife VAR in the study carried out by Floris et al. (2004).

\section{Side effects}

Marked population decrease of the treated colonies and a severe disturbance to the bees were recorded in the colonies treated with Var- away. It could be explained by an intense release of thymol resulted from using two strips of Var-away and the repeat of application three times. 
J. Agric. Sci. Mansoura Univ., 32 (3), March, 2007 T1 


\section{Thymol residues in honey.}

Results in Table (2) show a significant difference in the thymol residues levels among experimental groups $(P=0.013, \alpha=0.05$, one way ANOVA). However, there is no significant difference in the the thymol residues levels between Var-stop group and Var-away group $(P=0.744, \alpha=0.05)$.

The mean thymol residues in honey \pm standard error were $2.10 \pm 0.22$ $\mathrm{mg} / \mathrm{kg}$ for Var-stop, $2.02 \pm 0.12 \mathrm{mg} / \mathrm{kg}$ for Var-away, and $1.32 \pm 0.08 \mathrm{mg} / \mathrm{kg}$ for control group.

Table (2) : Honey thymol residues in treated and control colonies.

\begin{tabular}{|l|c|c|c|c|c|}
\hline & \multicolumn{5}{|c|}{ Thymol residues in honey $\mathbf{( m g / k g )}$} \\
\hline & $\mathbf{1}$ & $\mathbf{2}$ & $\mathbf{3}$ & $\mathbf{4}$ & Mean \pm S.E. \\
\hline Var-stop & 1.6 & 2.7 & 2.0 & 2.1 & $2,10 \pm 0,22 \mathrm{a}$ \\
\hline Var-away & 2.3 & 2.1 & 1.7 & 2.0 & $2,02 \pm 0,12 \mathrm{a}$ \\
\hline Control & 1.3 & 1.4 & 1.5 & 1.1 & $1,32 \pm 8,53 \mathrm{~b}$ \\
\hline
\end{tabular}

Means followed by different letters are significantly different at $\alpha=0.05$ (ANOVA followed by LSD test).

Mattila and Otis (1999) found that the mean thymol residue in Apiguard treated colonies was $3.3 \mathrm{mg} / \mathrm{kg}$ in honey from the honey super and 0.90 $\mathrm{mg} / \mathrm{kg}$ in honey from the brood chamber.

Floris et al. (2004) found that the residues varied from 0.12 to 4.03 $\mathrm{mg} / \mathrm{kg}$ for ApilifeVar and from 0.40 to $8.8 \mathrm{mg} / \mathrm{kg}$ for Apiguard.

Residues of thymol found in honey collected from treated beehives ranged from 0.75 to $8.20 \mathrm{mg} / \mathrm{kg}$ for Apilife VAR (Adamczyk et al., 2005).

Piasenzotto et al. (2002) found that thymol content, evaluated by the SPE-GC method, ranged between $0.02 \mathrm{mg} / \mathrm{kg}$ and $0.91 \mathrm{mg} / \mathrm{kg}$ in honey samples collected from hives that had been treated with a thymol-based acaricides.

The thymol residue in the honey from the colonies treated with Thymovar was $0.384 \mathrm{mg} / \mathrm{kg}$, (Donders and Cornelissen, 2005).

The obtained results were lower than those of Mattila and Otis (1999), Floris et al. (2004), and Adamczyk et al.(2005). However, they were higher than those obtained by Piasenzotto et al. (2002), Donders and Cornelissen, (2005).

Phenol and thymol are naturally occurred in botanical honey (Eucalyptus, Rosemary, Citrus, Heather and Biercol). Phenol exists in the five honey samples at levels between 15 and $318 \mathrm{ng} / \mathrm{g}$, while thymol was only found in Heather and Biercol honey at levels between 142 and $346 \mathrm{ng} / \mathrm{g}$ (Vinas et al., 2006). The WHO views thymol as generally safe up to concentration of $50 \mathrm{mg} / \mathrm{kg}$ (Imdorf et al., 1995). It has been demonstrated that, unlike other chemical acaricides, thymol does not accumulate in the honey or the wax, even after long-term use, if the instructions are followed. (Bogdanov et al., 1998).

In many countries, according to the National regulations, no official limits of thymol residue (max. min. levels) have been established for honey and wax (Wallner, 1999). However, foreign odors or tastes are not allowed in honey according to the European food legislation. Taste threshold was detected in honey at the concentration level of $1.1 \mathrm{mg} / \mathrm{Kg}$. 


\section{Thymol residues in wax.}

Results in Table (3) show no significant difference in the thymol residues levels among experimental groups $(P=0.132, \alpha=0.05$, one way ANOVA). The mean thymol residues in wax \pm standard error were $371.5 \pm$ $165.4 \mathrm{mg} / \mathrm{kg}$ for Var-stop, $475.0 \pm 140.9 \mathrm{mg} / \mathrm{kg}$ for Var-away, and $87.5 \pm 3.2$ $\mathrm{mg} / \mathrm{kg}$ for control group.

Table (3) : Wax thymol residues in treated and control colonies.

\begin{tabular}{|c|c|c|c|c|c|}
\hline & \multicolumn{5}{|c|}{ Thymol residues in wax (mg/kg) } \\
\hline & $\mathbf{1}$ & $\mathbf{2}$ & $\mathbf{3}$ & $\mathbf{4}$ & Mean \pm S.E. \\
\hline Var-stop & 212 & 867 & 181 & 226 & $371,50 \pm 165,43 \mathrm{a}$ \\
\hline Var-away & 582 & 806 & 152 & 360 & $475,00 \pm 140,99 \mathrm{a}$ \\
\hline Control & 96 & 84 & 89 & 81 & $87,50 \pm 3,27 \mathrm{a}$ \\
\hline
\end{tabular}

Means followed by different letters are significantly different at $\alpha=0.05$ (ANOVA followed by LSD test).

Our thymol residues results were higher than those obtained by Floris et al. (2004), who reported average wax residues of $21.6 \mathrm{mg} / \mathrm{kg}$ in the colonies treated with Apilife VAR and $147 \mathrm{mg} / \mathrm{kg}$ for Apiguard.

\section{REFERENCES}

Abou-Zeid, M. I. and Ghoniemy, H. I. 1993 : Evaluation of the role of two natural substances for controlling Varroa jacobsoni infesting honey bee colonies. Egypt. J. Appl. Sci. 8: 295-300.

Adamczyk, S.; Lazaro, R.; Perez-Arquillue, C.; Conchello, P. and Herrera, A. 2005 : Evaluation of residues of essential oil components in honey after different Anti-Varroa treatment. J. Agric. Food Chem., 53: 1008510090.

Anderson, D.L. and Trueman J.W. 2000 : Varroa jacobsoni (Acari:Varroidae) is more than one species. Experimental and Applied Acarology 24: 165-189.

Anonymous. 1999 : Recommendations from the CA 3686. The evaluation of a treatment against Varroa jacobsoni . Concerned action "Coordination in Europe of research on control of Varroa mites in honey bee colonies". Meeting Merelbeke. Belgium, November 13-14, 68-75.

Baggio, A.; Arculeo, P; Nanetti, A. and Marinelli, E. 2004 : Field trials with different thymol-based products for the control of Varroosis. American Bee Journal 144: 395-399.

Bogdanov, S.; Imdorf A. and Kilcheman V. 1998 : Residues in wax and honey samples after Apilife VAR treatment. Apidologie 29: 513- 524.

Calderone, N. W. 1999 : Evaluation of formic acid and thymol-based blend of natural products for fall control of Varroa jacobsoni (Acari: Varroidae) in colonies of Apis mellifera (Hymenoptera: Apidae). Journal of Economic Entomology 92: 253-260.

Colin, M., 1990 : Essential oil of Labiatae for controlling honey bee varoosis. J. Appl. Ent. 110: 19-25. 
DE Ruijter, A. 1987 : Reproduction of Varroa jacobsoni during successive brood cycles of the honey bee. Apidologie 18: 321- 326.

Donders, J. and Cornelissen, A. 2005 : Residue determination in honey after a spring treatment with Thymovar and formic acid. Apiacta $40: 1-4$.

Elsen, P. J.; Baxter, J. B.; Spivak, M. and Wilson W. T. 2000 : Control of Varroa jacobsoni oud. resistant to fluvalinate and amitraz using coumaphos. Apidologie 31: 437-441.

Elsen, P. J.; Eischen, F. A.;Baxter, J. B.; Pettis, J.; Elsen, G. W. and Wilson W. T. 1998 : Fluvalinate resistance in Varroa jacobsoni from geographic locations. American Bee Journal 138: 674-676.

Floris, I.; Satta, A; Cabras, P.; Garau, V. L. and Angion, A. 2004 : Comparison between two thymol formulations in the control of Varroa destructor: Effectiveness, Persistence and Residues. Journal of Economic Entomology 97: 187-191.

Gregorc, A. 2005 : Efficacy of oxalic acid and Apiguard against Varroa mites in honey bee (Apis mellifera) colonies. ACTA VET. BRNO, 74: 441447.

Haenel, H. and Koeniger, N. 1986 : Possible regulation of the reproductive of the honey bee mite Varroa jacobsoni by an host's hormone III . J. insect. Physiol. 32: 791-798.

Imdorf, A.; Bogdanov, S.; Kilchenmann, V. and Maquelin, C. 1995 : Apilife VAR a new varroacide with thymol as the main ingredient. Bee world 76: 77-83.

Imdorf, A.; Bogdanov, S.; Ochoa, R.I. and Calderone 1999 : Use of the essential oils for the control of Varroa jacobsoni oud. in honey bee colonies. Apidologie 30: 209-228.

Lindberg, C. M.; Melathopoulos, A. P. and Winston, M. L. 2000 : Laboratory evaluation of miticides to control Varroa jacobsoni (Acari : Varroide), a honey bee (Hymenoptera : Apidae) parasite. Journal of Economic Entomology 93: 189-198.

Lodesani, M.; Pillacani, A.; Bergomi, S.; Carpana, E.; Rabitti, T. and Lasagni, P. 1992 : Residue determination for some productus used against Varroa infestation in bees. Apidologie 23: 257-272.

Mattila, R. and Otis, G. 1999 : Trails of Apiguard, a thymol-based miticide. Part 1. Efficacy for control of parasitic mites and residues in honey. American Bee Journal 139: 947-952.

Milani, N. 1999 : The resistance of Varroa jacobsoni oud. to acaricides. Apidologie 30: 229-234.

Piasenzotto, L.; Gracco, L.; Conte, L. and Bogdanov, S. 2002 : Application of solid phase microextraction to evaluate traces of thymol in honey. Apidologie 33, 545-552.

SPSS Inc., Headquarters, 233 S. Wacker Drive, 11 th floor, Chicago, Illinois 60606.

Vinas, P.; Soler-Romera, M. and Hernandez-Cordoba, M. 2006 : Liquid chromatographic determination of phenol, thymol and carvacrol in honey using fluorimetric detection. Talanta 69: 1063- 1067.

Wallner, K. 1999 : Varrocides and their residues in bee products. Apidologie 30: $235-248$. 


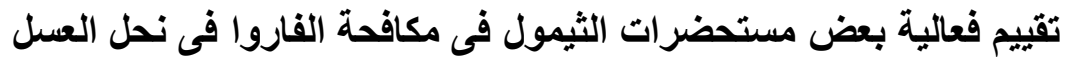

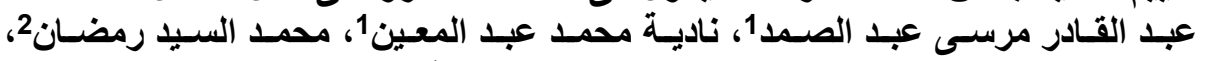

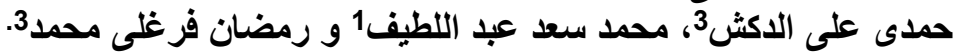

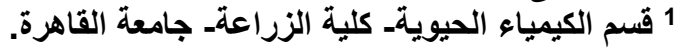

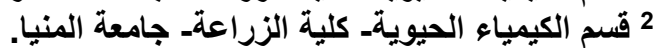
3 المعمل المركزى للمبيدات- الدقى- الجيزة.

أجريت هذه الدراسـة على أثنى عشرة طائفة مـن طو ائف نحل العسل فئ في منحل

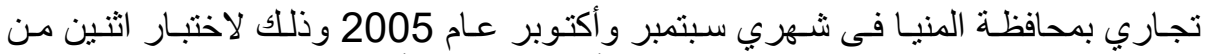

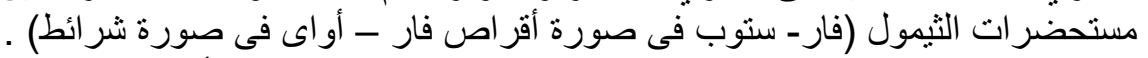

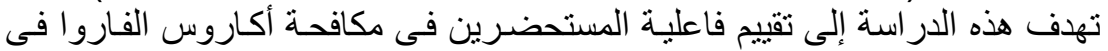

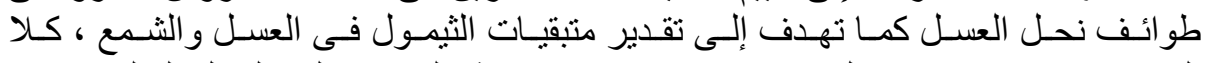

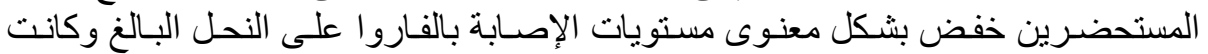

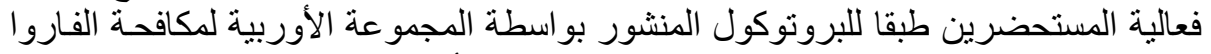

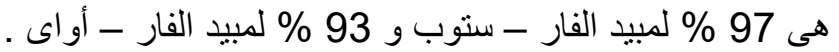

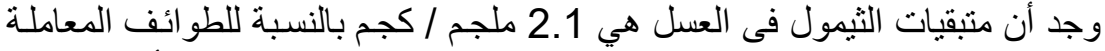

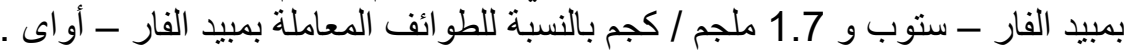

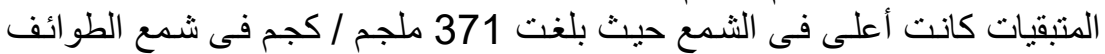
المعاملة بالفار - سنوب و 475 ملجم / كجم فى شمع الطوائف المعام المعلة بمبيد الفار - أو اي. 
Table (1): Total acaricidal effect of the two under- experimentation formulations,(Var-stop and Var-away).

\begin{tabular}{|c|c|c|c|c|c|c|c|c|c|c|c|c|c|}
\hline & \multirow{2}{*}{$\begin{array}{c}\text { No. } \\
\text { during } \\
\text { Tr. }\end{array}$} & \multirow{2}{*}{$\begin{array}{l}\text { No. } \\
\text { after } \\
\text { Tr. }\end{array}$} & \multirow[b]{2}{*}{ TN } & \multicolumn{6}{|c|}{ Efficiency of applications in (\%) } & \multirow{2}{*}{$\begin{array}{l}\text { TA } \\
\text { (\%) }\end{array}$} & \multirow{2}{*}{$\mid \begin{array}{c}M \pm \text { S.E. } \\
(\%)\end{array}$} & \multirow{2}{*}{$\begin{array}{l}\text { TA. } \\
\text { Ab. } \\
\text { (\%) }\end{array}$} & \multirow{2}{*}{$\begin{array}{c}\text { M } \pm \text { S.E. } \\
(\%)\end{array}$} \\
\hline & & & & $1^{\text {st. }}$ & MIS.E. & $2^{\text {nd. }}$ & 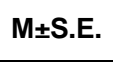 & $3^{\text {rd. }}$ & $M \pm S . E$. & & & & \\
\hline \multirow{4}{*}{$\begin{array}{l}\text { Var-stop } \\
90 \%\end{array}$} & 219 & 0 & 219 & 73.1 & \multirow{4}{*}{$\begin{array}{c}57.6 \\
\pm 6.2 \mathrm{a}\end{array}$} & 66.1 & \multirow{4}{*}{$\begin{array}{c}60.7 \\
\pm 3.0 \mathrm{a}\end{array}$} & 100.0 & \multirow{4}{*}{$\begin{array}{c}90.9 \\
\pm 5.4 \mathrm{a}\end{array}$} & 100.0 & \multirow{4}{*}{$\begin{array}{c}98.4 \\
\pm 0.8 \mathrm{a}\end{array}$} & 99.3 & \multirow{4}{*}{$\begin{array}{c}97.8 \\
\pm 0.8 \mathrm{a}\end{array}$} \\
\hline & 314 & 8 & 322 & 58.4 & & 52.2 & & 87.5 & & 97.5 & & 96.9 & \\
\hline & 821 & 1 & 822 & 42.3 & & 60.8 & & 99.5 & & 99.9 & & 99.3 & \\
\hline & 540 & 20 & 560 & 57.0 & & 63.9 & & 77.0 & & 96.4 & & 95.8 & \\
\hline \multirow{4}{*}{$\begin{array}{l}\text { Var-away } \\
42.5 \%\end{array}$} & 272 & 5 & 277 & 57.0 & \multirow{4}{*}{$\begin{array}{c}61.6 \\
\pm 1.5 \mathrm{a}\end{array}$} & 58.8 & \multirow{4}{*}{$\begin{array}{c}48.4 \\
\pm 3.7 \mathrm{~b}\end{array}$} & 89.8 & \multirow{4}{*}{$\begin{array}{c}82.2 \\
\pm 6.5 \mathrm{a}\end{array}$} & 98.2 & \multirow{4}{*}{$\begin{array}{c}96.4 \\
\pm 1.3 \mathrm{a}\end{array}$} & 97.6 & \multirow{4}{*}{$\begin{array}{c}95.7 \\
\pm 1.5 \mathrm{a}\end{array}$} \\
\hline & 321 & 11 & 332 & 62.7 & & 49.2 & & 82.5 & & 96.7 & & 96.1 & \\
\hline & 267 & 4 & 271 & 63.1 & & 44.0 & & 92.9 & & 98.5 & & 97.9 & \\
\hline & 429 & 35 & 464 & 64.0 & & 41.9 & & 63.9 & & 92.5 & & 91.4 & \\
\hline \multirow{4}{*}{ Control } & 104 & 494 & 598 & 6.5 & \multirow{4}{*}{$\begin{array}{c}5.1 \\
\pm 1.3 \mathrm{~b}\end{array}$} & 6.8 & \multirow{4}{*}{$\begin{array}{c}4.8 \\
\pm 0.7 \mathrm{c}\end{array}$} & 5.2 & \multirow{4}{*}{$\begin{aligned} & 4.6 \\
\pm & 0.6 \mathrm{~b}\end{aligned}$} & 17.4 & \multirow{4}{*}{$\begin{array}{c}13.9 \\
\pm 2.2 \mathrm{~b}\end{array}$} & 17.4 & \multirow{4}{*}{$\begin{array}{c}13.9 \\
\pm 2.2 \mathrm{~b}\end{array}$} \\
\hline & 135 & 618 & 753 & 8.1 & & 4.8 & & 6.2 & & 17.9 & & 17.9 & \\
\hline & 34 & 375 & 409 & 2.4 & & 3.0 & & 3.1 & & 8.3 & & 8.3 & \\
\hline & 113 & 832 & 945 & 3.4 & & 4.9 & & 4.1 & & 12.0 & & 12.0 & \\
\hline
\end{tabular}

Means followed by different letters are significantly different at $\alpha=0.05$ (ANOVA followed by LSD test).

$\mathrm{M} \pm \mathrm{S}$.E. = Mean \pm Standard Error.

No. during Tr.= Number of collected Mites during treatment.

No. after Tr.= Number of collected mites after treatment.

TN = Total Number of collected mites (experimental treatment and verification).

TA $(\%)=$ Efficiency of the treatment $(3$ applications) in (\%)

$\mathrm{TA}$. $A \mathrm{~b} .(\%)=$ Efficiency of the treatment ( 3 applications) according to the Abbott's 
J. Agric. Sci. Mansoura Univ., 32 (3), March, 2007

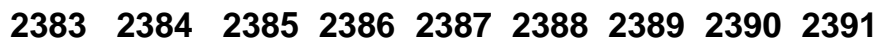

